Copyright (C) 2015 by Academic Publishing House Researcher

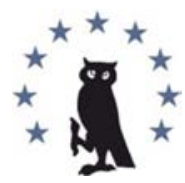

Published in the Russian Federation

European Researcher

Has been issued since 2010.

ISSN 2219-8229

E-ISSN 2224-0136

Vol. 96, Is. 7, pp. 502-510, 2015

DOI: 10.13187/ er.2015.96.502

www.erjournal.ru

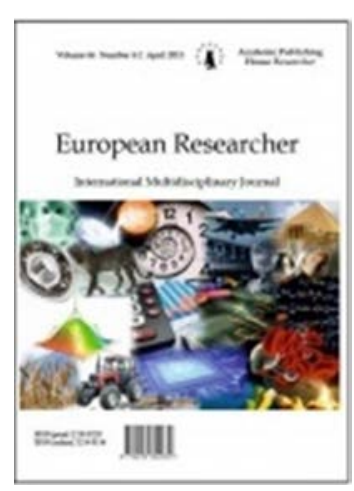

Pedagogical sciences

Педагогические науки

UDC 37

\title{
Iconographic Analysis of Media Texts on Media Literacy Education Classes
}

\author{
Alexander Fedorov
}

Anton Chekhov Taganrog Institute, Russian Federation

branch of Rostov State University of Economics

Prof. Dr. (Pedagogy)

E-mail: mediashkola@rambler.ru

\begin{abstract}
Iconographic analysis is associative analysis of the media texts' images (eg, water, fire - as symbols of purity and destruction) associated with the semiotic analysis. Art historians, scientists, semiotics, media theorists and practitioners of media education have written thousands of volumes, which convincingly proved that the decoding / decoding of audio-visual images sometimes difficult, requiring considerable knowledge and skills of the process of intellectual and creative work. Iconographic analysis of media texts based on the key concept of media language, and suggests that media education aims to develop knowledge of the ways in which media texts express his idea, and develop the knowledge, improving skills of textual analysis that can be attached to fixed or moving images recorded on the medium of sound or any combination of the above.

The initial stage of the iconographic analysis of media texts offer students concentrate on careful perception of audiovisual images on the description of their characteristic features. The audience learns conventional codes of media texts, followed by a smooth transition to the interpretation and evaluation of media texts. As a result, the audience media competence is developing in relation to visual images.

Keywords: iconographic analysis, media, media texts, media education, media literacy, media competence, students.

\section{Introduction}

Iconographic analysis is associative analysis of the media texts' images (eg, water, fire - as symbols of purity and destruction) associated with the semiotic analysis. Art historians, scientists, semiotics, media theorists and practitioners of media education have written thousands of volumes (among the most striking works I can recall the works of Y. Lotman, U. Eco, M. Yampolsky and many others), which convincingly proved that the decoding / decoding of audio-visual images
\end{abstract}


sometimes difficult, requiring considerable knowledge and skills of the process of intellectual and creative work.

Iconographic analysis of media texts based on the key concept of media language, and suggests that media education aims to develop knowledge of the ways in which media texts express his idea, and develop the knowledge, improving skills of textual analysis that can be attached to fixed or moving images recorded on the medium of sound or any combination of the above. In the critical work is usually done by analyzing the individual images or short fragments of a media text, offering a detailed account of what actually seen and heard - before moving on to the interpretive comments and express their reaction [Bazalgette, 1995, p. 31].

Here, cultural and aesthetic approaches in media literacy education (as well as an approach that focuses on the formation of "critical thinking") in common with the "semiotic" theory and methods of media education, involving reading and analysis skills, as a synthesis of signs and symbols, "codes".

The initial stage of the iconographic analysis of media texts offer students concentrate on careful perception of audiovisual images on the description of their characteristic features. The audience learns conventional codes of media texts, followed by a smooth transition to the interpretation and evaluation of media texts. There is also practiced training games' content: crop images and photos (the study of plans), shooting a video camera at different angles (the study of the concept of perspective), etc. As a result, developing audience media competence in relation to visual images.

\section{Materials and methods}

We use the materials of modern Russian and Western literature about un iconographic analysis [BFI, 1990; Semali, 2000, pp.229-231; Berger, 2005; Nechay, 1989, p.267-268]. We use also methods of creative tasks, contributing iconographic analysis of media texts, designed for gaming, role-playing possibilities of the pedagogical process, developing imagination, fantasy, associative thinking, the perception of nonverbal audience, media competence.

\section{Discussion}

In this case, of course, we take into account the curriculum developed by C. Bazalgette and her colleagues [BFI, 2003, p.7]: "freeze frame", "sound and vision"; "spot the shots", "top and tail", "attracting audiences", "generic translations", "cross-media comparisons", "simulation".

Quest freeze frame is that the teacher using the "Stop" the image of the video text, and students are trying to analyze the composition, lighting, color, angle in the frame, etc. Thus, an educational goal: the audience realizes that every element of the visual image has its value.

Quest sound and vision is based on the fact that the teacher closes the monitor screen and the students can hear only the sound track of a media text. After that, they will have to guess the content, genre, style proposed fragment, they try to think about what else may be possible musical accompaniment and the noise in the media text. Here the students to understand the importance of practice and especially sound solutions movies or TV shows, especially the combination of a number of sound and image.

Creative activity spot the shots is intended for the final students' understanding of the fact that each frame has some information that there is a mounting frame rate, etc. That is, here again studied language media.

Creative activity top and tail provides viewing audiences elementary media text frames, on the series of which they must guess the genre of the work.

Studying the mechanisms of attracting audiences is intended that students collect a package of various kinds of information on media culture (reviews, advertisements, photographs, soundtracks, etc.), on the basis of which it is possible to prepare the group "presentation" of a media text or make a collage its theme.

Quest generic translations develops students' ability to "transfer" of media texts from one type to another (ie, from a literary text in the screen and, on the contrary, from the newspaper - in verse, etc.).

Creative activity cross-media comparisons is that students are asked to compare the two fragments of different works for different audiences. For example, it is necessary to compare the 
key episodes of the literary text and its two adaptations. Or compare the interpretations of the same themes in fiction and documentary form.

As we can see, in general, this technique is fully consistent with the theory of the six key aspects of media literacy education, which is among the supporters - Cary Bazalgette, Andrew Hart, and many other media educators.

Knowledge and creative skills, obtained an audience with the development of introductory, practical steps, prepare them for classes, to develop the perception of media texts created by professionals contributed to the beneficial implementation of the educational process within the specialization "Media Education". Argue that with sufficient confidence, as in the experiment tested two versions of media insight: 1 ) with discussions of media texts professional writers; 2) the same, but with a preliminary cycle of practical creative tasks, introduces the audience to the laboratory creation of media texts. The second option was more productive. After media literacy education classes, creative nature of the audience is not only fluent in more specific terminology, but also faster, described in detail in speech iconographic elements. Knowledge and skills related to "kitchen" of the creative process of creating media texts to help students accurately express their feelings about what they saw and heard, indirectly, to develop their abilities to perceive, to a certain extent prepare them for subsequent critical analysis skills (because without the ability to describe their experience we can not talk about the full analysis of media texts).

W rely also on the idea of outstanding Russian media educator Yury Usov (1936-2000), that "the perception of sound and vision image is a visual experience of tempo, rhythm, form the subtext of plastic film narration; the result of this experience is sensual and intellectual associations that arise in the process of perception of the sound and vision series of plastic composition and its components are synthesized in the figurative generalization which contains in itself the author's concept, multi-dimensional artistic ideas"[Usov, 1989, p.235].

\section{Results}

Iconographic analysis of media texts implies a number of students of creative tasks [BFI, 1990; Semali, 2000, pp.229-231; Berger, 2005; Nechay, 1989, p.267-268; Fedorov, 2004, p.43 -51; Fedorov, 2006, p.175-228, but I substantially supplemented and revised the cycle of works): literary and analytical, drama, role-playing, fine-simulation. Each of these tasks involves analysis of the key concepts of media literacy education (media agencies, media categories, media language, media technologies, media representations, media audiences, etc.).

Cycle of literary analytical creative tasks that contribute iconographic analysis skills in the classroom at the student audience:

Media agencies:

- analysis of the logos of famous media agencies / firms with visual (composition, color, etc.) point of view.

Media / media text categories:

- analysis of the volume of a media texts (newspapers, Internet), dedicated to the image (photographs, drawings, etc.), or promotional materials, and volume for verbal texts (articles, dialogs, etc.).

Media technologies:

- analysis of the technologies of visual media texts in a number of specific types and genres.

Media languages:

- comparison of the composition in painting, drawing, sculpture, photography, film / TV;

- View DVD / video media text's episode without sound, in order to focus on the characters' facial expressions, gestures, a color, lighting in the scene and shoot types (plans, camera angles, camera movement); view the same episode with the sound, to get a clearer picture of how the effect is achieved by a media text on the audience (including the impact of specific techniques).

Media representations:

- comparison of two frames (two photographs, drawings), where the same scene is depicted in various ways. Thinking about how to change the angle affects your perception, understanding the relationship of media text characters to each other;

- analysis of promotional posters of media texts (visual and written information, the most important part of this information, indicate the genre of media texts, composition posters); predicting the success of a media text advertised in the audience; 
- selection of multiple advertisement texts from the expensive and cheap magazines; determining the difference as an advertisement in the nature of the advertised goods and services in the exterior image of a male and female characters;

- selection of multiple photos or posters of different years, depicting beautiful women and men; determination of the total in these images, the changes over the past decade, the criteria of human beauty and the way in which media texts reflect these changes.

Media audiences:

- analysis of a number of images from the media texts with various uses of space; conclusions about the taste, social class, gender and age of the people, which the authors regard as the target audience.

It is also possible iconographic analysis of media texts (drama, melodrama, comedy, detective story, thriller, western, science-fiction, horror, TV news, TV interview, reality show, game show, talk show, etc.) using tables with typical iconographic stereotypes, typical visual images of feelings' conventional codes (hunger, thirst, satiety, fear, terror, joy, delight, sexual attraction, sexual aversion, love, hatred, pity, compassion, indifference, envy, jealousy, timidity, shyness, aggression, arrogance, etc.), visual images of typical places for media texts (reach/poor house, saloon / bar / restaurant, business office, educational institution, army barracks, ship, submarine, police department, prison, etc.).

Cycle theatrical role-creative tasks that contribute to the iconographic analysis of media texts in the classroom at the student audience:

Media agencies:

- business game "Create a newspaper / magazine / internet site";

- pantomime's presentation of media logo.

Media / media text categories:

- preparing pantomime within any genre media relying on a certain visual plastic solution;

Media technologies:

- practically implementation (in small creative groups, armed, for example, digital video camcorder) to certain media technology based on one or another way of viewing.

Media languages:

- shooting short movie (duration: 2-3 min.) "The game of chess", "My class", etc. using different methods of visual recording;

- shooting TV news using various visual ways of shooting;

Media representations:

- "frozen" figure on the themes of the stories and characters of media texts;

- pantomime on topics of plots and characters of media texts;

- role game on the topic of "International meeting of media critics" with discussion about various aspects related to the iconographic analysis skills.

Media audiences:

- preparing pantomime, visually reflecting different emotional audience's reactions (audience can be different ages and social status) to media texts.

The purpose of many of these creative tasks: the development of students' media competence in area of visual media texts. These tasks prepared students for the creation of mini-movies, radio / TV programs, interactive newspapers and magazines, Web sites, computer animation, etc. (with a pre-written plans and scenarios).

Implementation of theatrical role-creative tasks based on role game: students have the function of "directors", "operator", "actors", "journalists" and so forth. After the rehearsal period the students' team to begin practical establishment media text (short video or television program, Interactive website, newspaper, etc.). Their interpretations are compared, discussed the advantages and disadvantages.

The role of the teacher in the process of performing such tasks: to demonstration for the audience the media technology (video, video recording and video projection, computer), tactful correction to the implementation of tasks and participation in the discussion of the results. In other words, the audience receives the greatest possible scope for imagination, personality expression of his thinking and creativity.

The specific tasks to help iconographic analysis of media texts: 
- "journalist" (practical layout of Interactive newspaper or magazine, the selection of the most spectacular illustrations, photographs);

- "directing" (guide the process of shooting, including: the definition of the main decorations, sound and music, light-color solutions, taking into account the genre and stylistic features of the product, etc. ;

- "camera man" (practical implementation of the plans, perspectives, staging, camera movement, frame, light, etc.);

- "decorative-art" (the use of natural scenery, costumes, design Interactive sites, computer animation, etc.).

Undoubtedly, this kind of classes are purely educational and are not intended to create media texts that claim to professional level. But the process of students' understanding of audiovisual language, the development of students' creative abilities is important.

As a result, theatrical-game tasks, as well as literary simulations, help to form the following qualities corresponding to various indicators of individual media competence: knowledge of the basic steps in the process of creating media texts; use of media works functions in different forms and genres; emotional, artistic motives for the contacts with the media (motivational indicator); creative, artistic ability in the works for own media texts (creative indicator).

Graphic-cycle simulation creative tasks that contribute to the iconographic analysis skills in the classroom at the student audience:

Media agencies:

- transformation of a logo of some well-known company, the justification for that visual changes.

Media / media text categories:

- preparing pictures, posters, collages, reflecting the visual stereotypes of a media texts' genres.

Media technologies:

- selection of image media technologies (tools and forms images in photographs, drawings, magazine illustrations, etc.) for the simple story;

- experiments with various forms and technologies in order to study how they are used for the transmission of specific texts, "messages" of visual symbols;

- use of different techniques in the planning and creation of media texts, careful and critical analysis of the results obtained;

Media languages:

- preparation of a series of frames that could be used as a basis for chase scenes in the detective story (with support for various types of crop - the general plan, close-up, detail, etc.);

- creation and presentation of visual media project based on graphic symbols.

Media representations:

- analysis of the frame (photos, advertising posters) from the point of view of what is happening there. Manufacturing clippings figures or objects depicted in photographs or poster. Different arrangements of these clippings in the "frame". Meditating on the fact whether the changed attitude of the characters and items after these transpositions;

- creation of a different visual angles based on the same image (with a change in its components);

- read scenic line (for example: "He is standing on the bridge, takes a few puffs and throws himself into the water"). Training (using sheets-frame) series of frames "the film adaptation of" this scenic line;

- creation of a poster or collage based on texts and images clippings from old newspapers / magazines;

- creation of a diorama scene of media texts;

- creation of a picture book;

- creation of a advertising billboards for own media texts (variant: posters for professional media texts) with the help of photo collage with additional drawings or based on their own original drawings;

- creation of a cartoon "comic" based on those or other media texts;

- creation of a game based on the popular media texts;

- development of a maps with the media text's history; 
- manufacturing of finger puppets depicting certain scenes of a media text, staging puppet show in some episodes; dialogues;

- creation of animation: your own animated version of the characters, the writing of

Media audiences:

- creation of visual media texts intended for a specific audience, foreseeing how the audience might react to such media products;

- creation of pictures or draw comics, reflecting different emotional reactions audiences of all ages and social status to certain media texts.

After performing the above tasks is a contest of creative posters, collages, drawings, comics, visual projects students can discuss, compare their advantages and disadvantages, answer the questions from the teacher and audience, etc.

The main indicator of these works: the ability of students in the non-verbal forms to express their impressions about the media text. My experiments showed that the written work and oral interviews can not always afford to fix accurately the true level of students' media competence. And students often simply not able (undeveloped speech, shyness, lack of practical skills of public discussion about media text) transfer his impressions in words.

For example, in individual conversations with the help of leading questions I have been able to establish that some students who was in the written work and group discussions in the level of "primary identification" (ie, the perception of the chain of events of a media text, without realizing the position of heroes and authors), actually see and understand much more about the characters in the media text and media environment. And creative nonverbal tasks can to maximize their level of media competence. For example, painting advertising posters, students (even with poor vocabulary and complete writing inability) found sometimes "hidden" creative thinking, the ability, based on intuition, to create a piece of paper (using paints, markers, pencils, clippings from illustrated magazines and applications), reflected the concept of media text.

Series of media literacy education classes designed to develop skills in the audience to the iconographic analysis skills using creative tasks to restore the memory of the dynamics of audiovisual images episodes of media texts in the process of collective discussion.

In addition, the most important indicator for full perception of audiovisual media texts in the course of lessons to keep in mind the audience mastering features of the composition frame, its spatial, light-color, sound, field-aligned solutions, which in synthesized form carries meaning. The audience should also possess a kind of mounting thinking: emotional state of the semantic elements of the narrative, their rhythmic, plastic compound in the frame, episode, scene, so that eventually the perception of media texts based on the relationship of several processes:

- perception of dynamically developing visual images; stored in the memory of previous audio-visual, spatial and temporal elements of media image;

- prediction, foreboding probability of a phenomenon in the media text. In order to carry out these tasks in relation to the audiovisual media, the audience is invited to make an attempt to describe the dynamics of the deployment in the media image rhythmically organized plastic narrative form. The basis of this process can be a discussion of the mounting (with the rhythm, tempo, etc.) a combination of frames (taking into account their composition: the front, depthaligned, light-color, etc.) and episodes, as the dynamics of the formation of the audiovisual image it manifests itself in the interaction of training and installation.

The purpose of these studies is that the students, talking to the media, to develop their emotional, creative activity, non-verbal thinking, sound and vision memory, because of what facilitated the analysis and synthesis of the sound and vision, space-time image of the media text.

Here are excerpts from the analytical work of students related to the iconographic analysis of media texts:

"It is very interesting final of media text. A picture of the broken, looted, burned with fire New York XIX century. And gradually, this image is replaced by today's New York. Against this background, the music sounds. This technique the authors would like to say that life is changing, and the people and the problems remain the same. New people new world do not remember or do not know their history, and therefore make the same mistakes as their ancestors ..." (Maria B.). 
"Sad mood shown by means such as wet weather is rainy, gray streets. Loneliness hero stressed uncomfortable situation apartment, his monologues facing the dead wife. (...) The idea of authors show that the deceived person deprived of life of the rod, condemned to death" (Ellen G.).

"In the final episode, we see an empty car with fading in the twilight of the sounds of a mobile phone lights. Gradually the lights will go out of the machine, and the phone is switched off ... These two symbols indicate that they have recently used by people who are no longer alive. The essence of the author's message: do not "chase the death" and too much to hope for good luck. This frame is a pity the lost characters who flew dangerous to life at full speed ..." (Anna M.).

Questions to the iconographic analysis skills in the classroom at the student audience [Buckingham, 2003, pp.54-60; Berger, 2005, p.49, 92, 99, 124, 145; Media ... 2005, p.365 Fedorov, 2004, p.43-51; Fedorov, 2006. pp.175-228]:

Media agencies:

Does media agencies use in their logo images reflecting their real activity? If not, why not? What visual solutions, denoting a particular company, the most common?

Media / media text categories:

Is there a difference in the approaches to the use of color and light in media texts of different types and genres?

As visual codes and conventions occur in different types of media texts?

Media technologies:

As visual technologies influence the creation of media texts?

Media languages:

What fonts are used in media texts, and what information they carry?

What is the relationship between image and text elements in printed advertising media text?

What style of language and speech techniques used in the text posted on this promotional poster?

As space is used on posters? Why do you think it's done this way?

What angle used in this poster / photo / frame? What type of lighting? How to use color?

As media use different forms of visual language to convey ideas or values?

How is the use of visual language becomes clear and generally accepted?

What are the effects of the choice of certain forms of visual language media?

What is the relationship between the various objects that we see in the picture?

How to depict people and objects in a particular episode?

Do you see the visual symbols, signs in this in a media text? If so, what?

If the advertising poster depicts people and / or animals, describe how they look? What does the background on which they are depicted? How this relates to the background image acts?

Do you see the tradition of the great masters of painting in the visual range of contemporary media texts?

Can you think of examples of landscapes, portraits, still lifes in media texts?

Media representations:

Whose eyes see (someone told) events in a particular episode of a media text?

As the authors of media texts can pictorially show that their character has changed?

Do you know the sound and vision signs for the creation a sense of danger or surprise in media text? family?

What the photos from your family archive of different years can tell us about you and your

Record the same "news of the day" with two TV-channels, compare the visual and verbal organization of these two options (display order fragments, visualization, comment, work of operators). What can you say about the differences that are found?

Media audiences:

What about the audience's emotional reaction to the iconic series of media text?

What is the difference between pictures / movies made in relation to the same object for tourists or research scientists?

What do you know about the influence of light and shade on the perception of the audience? 


\section{Conclusions}

In this article I presented the main directions for Iconographic Analysis on media education classes for student audience, including the examples of creative problems and issues associated with this type of the analysis in the context of media education problems, ie based on six key concepts of media literacy education: agency, category, language, technology, audience, representation. I suppose that the Iconographic Analysis of media texts on media education classes can significantly develop media competence of students, including critical thinking and media perception.

\section{References:}

1. Bazalgette, C. (1995). Key aspects of media education // Report on the Russian-British seminar on media education. Moscow.

2. Berger, A.A. (2005). Seeing is believing. Introduction to visual communication. Moscow: Williams, $288 \mathrm{p}$.

3. BFI Department for Education (2003). Look Again! The Teaching Guide to Using Film \& Television with Three to Eleven-year Olds. London: British Film Institute, $60 \mathrm{p}$.

4. Buckingham, D. (2003). Media Education: Literacy, Learning and Contemporary Culture. Cambridge, UK: Polity Press, 219 p.

5. Fedorov, A.V. (2004). Specificity of media pedagogical students // Pedagogy. 2004. № 4, pp.43-51.

6. $\quad$ BFI (British Film Institute). (1990). Film Education. Moscow, 124 c.

7. Fedorov, A.V. (2006). Media Education: creative tasks for students and pupils // Innovation in Education. 2006. N4, pp.175-228.

8. Media. Introduction (2005). Moscow: Unity-Dana, 550 p.

9. Nechay, O.F. (1989). Fundamentals of cinema. Moscow: Education, 1989, pp. 167-168.

10. Potter, W.J . (2014). Media Literacy. L.A.: Sage.

11. Semali, L.M. (2000). Literacy in Multimedia America. New York - London: Falmer Press, $243 \mathrm{p}$. 449 p.

12. Silverblatt, A. (2001). Media Literacy. Westport, Connecticut - London: Praeger,

13. Silverblatt, A. (Ed.). (2014). The Praeger Handbook of Media Literacy (in 2 volumes). Santa Barbara, California and Oxford, England: Praeger.

14. Usov, Y.N. (1989). Film education as a means of aesthetic education and artistic development of pupils. Ph.D. Dis. Moscow, 362 p.

\section{УДК 37}

\section{Иконографический анализ медиатекстов на медиаобразовательных занятиях}

\section{Александр Федоров}

Таганрогский институт имени А.П. Чехова, филиал Ростовского государственного университета экономики, Российская Федерация Доктор педагогических наук, профессор

Е-почта: mediashkola@rambler.ru

Аннотация. Иконографический анализ - это ассоциативный анализ образов медиатекстов (например, вода, огонь - как символы чистоты и уничтожения), связанных с семиотическим анализом. Искусствоведами, учеными-семиотиками, медиатеоретиками и практиками медиаобразования написаны тысячи томов, где убедительно доказано, что декодирование аудиовизуальных образов иногда трудный процесс, требующий значительных знания и навыков в процессе интеллектуального и творческого труда. Иконографический анализ медиатекстов на основе ключевого аспекта «язык медиа» предполагает, что медиаобразование стремится развивать знания о путях, где медиатексты выражают свою идею, повышать умения анализа медиатекстов, который может относиться 
как к фиксированным, так или движущимся изображениям, записанным на любых носителях.

Начальная стадия иконографического анализа медиатекстов предлагает студентам сосредоточиться на тщательном восприятии аудиовизуальных образов, на описании их характерных особенностей. Аудитория изучает стереотипные коды медиатекстов, с последующим плавным переходом к интерпретации и оценки медиатекстов. В результате, развивается медиакомпетентность аудитории в отношении зрительных образов.

ключевые слова: иконографический анализ, медиа, медиатексты, медиаобразование, медиаграмотность, медиакомпетентность, студенты. 